\title{
Political Connection and Enterprise Development (A case study of Nishat Business Group)
}

\author{
Dr. Ayesha Shoukat \\ Assistant Professor, The Islamia University of Bahawalpur.Corresponding AuthorEmail: ayesha.shoukat@iub.edu.pk
}

\author{
Muhammad Sajjad \\ Assistant Professor, The Islamia University of Bahawalpur
}

Samreen Ramzan

Lecturer, The Islamia University of Bahawalpur

\begin{abstract}
This paper explores what role political connections of any business group of developing country have in its expansion and growth. Starting from explaining the different mediums through which business groups are related to politics, we focus to investigates a little studied but common mechanism that firms use to obtain state favors: business owners use political connections to seek influence to the top offices and commercial banks. Using Pakistan's biggest private business group as a case study, we find that the accessibility to loans of the business group in favored political regimes is beyond the approved range. Once their favored ruling party is in power, the debt to equity ratio of these firms had increased dramatically without supportive increase in ROA and ROE. Same as, the other descriptive discussion on the strategic decisions of this group enabled us to infer about the benefits business group had availed during its favored regimes. So we conclude that the political power does influence the financing strategies of politically connected business group. Due to which their accessibility to bank loans facilitated them to expand their businesses and capture more market share.
\end{abstract}

Keywords: Political connection, Loan accessibility, Regimes, Politics, Military, Democracy.

Article Received: 18 October 2020, Revised: 3 November 2020, Accepted: 24 December 2020

\section{Introduction}

In research of business groups, multiple definitions have been employed when describing these enterprises. According to Khanna and Rivkin (2001) business groups are firms which, though legally independent, are bound together by a constellation of formal and informal ties and are accustomed to taking coordinated action.

Business groups earn special favors from ruling government by either participating directly in politics or by developing acquaintances with ruling elites. There are researchers like (Bunkanwanicha and Wiwattanakantang 2009, Gomez 2009) who focused their studies on business groups which get direct involvement in politics in Malaysia and Thailand respectively. But many studies examine the indirect methods firms use to obtain state favors other than business owners themselves participate in elections for top political office.

The other indirect famous medium to win government favors is through Political connections. A firm is defined as politically connected if at least one of the firm's largest shareholders or top officers is a member of parliament, a minister, a head of state or is closely related to a top official (Faccio, Masulis, and McConnell 2006) or the CEO is a current or former officer of the central government, local government or the military (Fan, Wong, and Zhang 2007) or if its CEO attended elite schools and was employed as a civil servant or had a government position (Bertrand et al. 2008) or if their executives and supervisory board members were close to the ruling party (Ferguson and Voth 2008) and lastly, if at least one member of its board of directors or its supervisory board is or 
was a politician (Boubakri, Cosset, and Saffar 2008).

The incentive for corporations to become politically connected has been recognized among economists for many years and by citizens of affected countries for many more. As economists have noted, rents from the state can take various forms, including preferential treatment by government-owned enterprises (such as banks or raw material producers), lighter taxation, preferential treatment in competition for government contracts, relaxed regulatory oversight of the company in question, or stiffer regulatory oversight of its rivals. However, as emphasized by Shleifer and Vishny (1994) corporate elites benefit from their access to state rents when the marginal benefits of the connections outweigh their marginal costs which the business had to pay for establishing such connections. Politicians create and maintain stateowned banks not to channel funds to economically efficient uses, but rather to maximize their own personal objectives.

There is broad agreement among scholars that business groups are a phenomenon of great theoretical and practical importance, but key points of contention and ambiguity remain regarding their financial performance and strategies. Cuervo-Cazurra (2006) further divided business groups along three lines: as family owned, widely-held and state-owned. Of these types, this study will only follow one type: familyowned business group and for it the group selected in Nishat Group. This group is considered as Pakistan's top business group from last twenty years and the Head of this group, Mian Mansha is considered to be the richest man of Pakistan. The basic purpose of this analysis is to assess the impact on the development and success of Nishat Group and understand the role of political connections and collusions with other business groups in its exemplary success. The definition followed in this study for family-owned business group is, as one where individuals or families are involved in the ownership, control and management of business firms; this is the definition given by Cuervo-Cazurra (2006).

\section{Literature Review}

A large body of empirical work has demonstrated that firms with political collusions enjoy exceptional access to government loans and, for this reason, are more likely to resort to excessive leverage during decision-making about the financing of their business activities (Desai and Olofsgård 2011, Faccio, Masulis, and McConnell 2006, Fan, Wong, and Zhang 2007, Fisman 2001). This view supports a positive relationship between a business group's political collusions and the degree of financial leverage (Claessens, Feijen, and Laeven 2008, Li et al. 2008, Saeed 2013). Nevertheless, there are studies indicating the inverse, or a complete lack of relationship between political collusions and leverage (Asquer and Calderoni 2011, Bunkanwanicha., Fan, and Wiwattanakantang 2008). In light of such diverse findings, it is difficult to draw a definitive conclusion regarding the impact of collusions and networking on a firm's financial leverage.

Extensive anecdotal evidence indicates that influential firms maintain banks as offshoots of their businesses. Studies focusing on the Pakistani context argue that private banks in general and government banks in particular appear to extend loans based on personal ties rather than on the basis of collateral and future cash flow. Financial institutions such as Habib Bank are famous for providing non-repayable loans to industrialists (Khawaja and Mian 2009, Saeed 2013).

In Pakistan, the top performing firms are mostly associated with business groups (Ghani, Haroon, and Ashraf 2010). The business groups in Pakistan (previously known as "twenty-two families," hereafter named "The families") are informal combinations of legally independent business entities run by families. The family patriarch is the dominant shareholder and manager, and immediate and distant familymembers help operate various firms within the business group. It is common for these family members to belong to the same religious sects or 
communities. Some examples of major business communities are the Chiniotis, Memons and Ismaeelis/Aga Khan families with business origins (primarily trading, some in manufacturing) in parts of India, who later migrated to Pakistan (Amjad 1976, Ghani, Haroon, and Ashraf 2010, Papanek 1972, Rashid 1980).

. However, what needs to be studied are the ways in which the contextual characteristics of a country support the creation of business groups, including by providing opportunities for diversification (Lee, Peng, and Lee 2008) or by inducing the transformation of business groups (Ahlstrom et al. 2004). Institutions have multiple dimensions, including political, legal and economic factors. They are closely connected and mutually reinforcing (Whitley 1994). Therefore, institutional transitions may manifest diverse patterns due to different dimensional changes at different speeds.

As changes in the institutional environment may negatively affect the business group (Carney and Gedajlovic 2002) so too might group affiliation reduce the negative impact (Wang, Huang, and Bansal 2005). This suggests that business groups may also influence changes in the institutional environment (Luo and Chung 2005) although such institutional changes may not have the consequences that were initially intended (Steven 2004). All this will help generate contextualized knowledge that contributes to a better understanding of firm behavior (Tsui 2004).

Therefore, the case study of the business group in this article pays close attention to the institutional context of Pakistan. An attempt is made to evaluate the performance of Nishat Group from their date of incorporation up to 2012. This mode of evaluation is also undertaken in order to determine the role of the government in the performance of this group.

Business networks substitute for reduced market share and hence add value to network participants (Leff 1976). For example, Khwaja, Mian, and Qamar (2008) concluded that in Pakistan more than 5,000 firms are connected via a single network of interlocking boards and these firms gain access to financing. Network membership improves access to credit and the financial viability of member firms by a rate of 16.65 per cent. Membership decreases the firms' propensity to enter financial distress by 1.7 percentage points. Scholars continue to focus on firm size for a variety of reasons. The foremost seems to be that size is a proxy for resources and provides some indication of the firm's ability to become politically engaged (Schuler and Rehbein 1997). Size may also represent political (more stakeholders $=$ more voters) and economic power (a large firm may capture many of the rents through public policy). For example, Hillman and Hitt (1999) assert that firms with greater financial and intangible resources are more likely to engage in CPA alone while those with fewer are forced to work collectively with others. In a set of medium and small sized companies, Cook and Fox (2000) show somewhat surprisingly that the smallest were the most politically active. However, they also find smaller firms joining with others to participate in CPA, which supports Hillman and Hitt's assertion regarding collective participation (Hillman, Keim, and Schuler 2004). In this study, firm size is measured by assets and the equity acquired; therefore, the ratios measured are returns-on-asset (ROA) and returns-on-equity (ROE).

The other variables which are measured to see the influence on business group firms' performance are the group's product diversification (Hillman and Hitt 1999)(Schuler, 1998) foreign ownership (Getz 1996, Hansen and Mitchell 2000) firm age (Hansen and Mitchell 2000) reputation (Baron 1995, Boddewyn and Brewer 1994, Keim and Baysinger 1988) and experience or credibility (Hillman and Hitt 1999)(Hillman, 2003). These factors have been considered while measuring the change in a firm's strategy under different regimes which also shows the extent to which a group has been politically active in a particular regime.

Papanek (1972) evaluated from pre-partition the influence of these big business groups on the The involvement of the corporate elite in Pakistani politics directly or indirectly is evident. Referring 
to the corporate elite as "robber barons" in their studies, Maniruzzaman (1966) and Raman (2014) argue that while this might be considered a natural phenomenon, it should not be at the cost of a country's prosperity. Along with socio-economic problems, Pakistan's economy is seeing a massive distortion of its growth, while the business groups of the corporate elite are becoming bigger and wealthier. The cost of this increased economic strength needs to be analyzed.

In this article, we will examine the effect of the changing pattern of ownership structure on the corporate decisions of Nishat Group being the leading business group. Specific attention is given to the use of state patronage and political connections by this business groups which shaped the current economic and corporate structure of Pakistan. This serves as a guide for predicting the future patterns of development and the strategies which the government needs to follow to safeguard long-term economic development.

This study contributes to the literature by examining the impact of political ties on the performance of public listed firms associated with Nishat group. The reasons to select a business group of Pakistan for studying this relationship are many. First, because the use of political connections by business groups is a common practice in Pakistan and politicians tend to have significant influence in the corporate world (Khawaja and Mian 2009, Saeed., Belghitar, and Clark 2014). Second, the underdevelopment of capital markets, inadequate institutional support, and overarching governmental control and intervention create impediments for business.
Consequently, establishing a close relationship with politicians in Pakistan or having direct political participation is taken as an effective strategy for businesses to overcome market failure. Lastly, to curb political corruption, the Pakistani government undertook drastic steps. Importantly, the National Anti-Corruption Strategy (NACS) was introduced in 2002 with the aim of eradicating corruption from the political system. However, some recent, widely publicized political corruption scandals (Rental Power Projects, Pakistan International Airline case) cast doubts on the efficacy of such government initiatives. Arguably, such initiatives were not effective in stopping politicians from engaging in rent-seeking activities. Thus, it is worth examining the extent of political patronage within the Pakistani context, focusing specifically on the rise of big business groups under different regimes.

\section{Research Methodology}

The methodology adopted for this study is qualitative in nature. This study's primary concern is to determine the impact of political connections on the rise of the biggest business group, Nishat, under different regimes. For this reason, detailed financial and political connection analyses of public listed companies of above mentioned business groups, from their date of incorporation until 2012, is provided. The time period studied is divided on the basis of epochal bracketing see Table 1. The focus is on the occasions when regime changes occurred between the military and civilian governments.

\section{Table1}

Classification of regimes.

\begin{tabular}{|l|l|l|l|l|l|l|l|}
\hline $\begin{array}{l}\text { Regime 1 } \\
\text { 1BR }\end{array}$ & $\begin{array}{l}\text { Regime 2 } \\
\text { 1MR }\end{array}$ & $\begin{array}{l}\text { Regime 3 } \\
\text { 2MR }\end{array}$ & $\begin{array}{l}\text { Regime 4 } \\
\text { 1DR }\end{array}$ & $\begin{array}{l}\text { Regime 5 } \\
\text { 3MR }\end{array}$ & $\begin{array}{l}\text { Regime 6 } \\
\text { MD }\end{array}$ & $\begin{array}{l}\text { Regime 7 } \\
\text { 4MR }\end{array}$ & $\begin{array}{l}\text { Regime } \\
\text { 8 } \\
\text { 1DT }\end{array}$ \\
\hline $1947-57$ & $1958-68$ & $1969-71$ & $1972-77$ & $1978-88$ & $1989-98$ & $1999-07$ & $2007-12$ \\
\hline
\end{tabular}

\section{Source: Author}

The business group was studied employing three major forms: First, using a business history approach; second, measuring its rise and fall under different regimes using financial analysis; 
and, finally reaffirming the findings of the business history approach and financial analysis by employing statistical methods to grade the performance of each group under different regimes. These methods were used to assess the (best and worst) performance of the groups' publicly-listed companies under these regimes. This method is employed to ascertain what had happened under each regime as well as the support provided by each regime to Nishat Group.

Although there are various accounting measures used to quantify performance, for the purpose of this study two measures were adopted, return on assets (ROA) and return on equity (ROE), as in similar works studying the outcomes of political connections on firm performance (Boubakri, Cosset, and Saffar 2008)(Dombrovsky, 2008; Fan, et al., 2008). ROA is used to assess the ability of firms to generate returns on total assets available (Tezel \& McManus, 2003). This is defined as profit-after-taxes over average assets multiplied by $100^{1}$. ROE is used to evaluate the return on money that shareholders have invested (Brigham, et al., 2004). In this study, it is defined as profitafter-taxes divided by the total equity multiplied by $100^{2}$.

For measuring loan accessibility of listed firms of business groups, a debt-to-equity (DTE) ${ }^{3}$ ratio is

An increase in ROA can be due to two reasons: either the ${ }^{1}$ asset base is reduced or profitability of the company has increased. If the investment remains constant and profitability increases, this is good for the company. But if the ROA increases due to a decrease in assets, this is not healthy as it could be the result of investment withdrawals or asset sales.

An increase in ROE can be due to an increase in ${ }^{2}$ profitability or reduction in equity which happens due to a reduction in shares issued or reserves withdrawal. Equity is considered to be the most expensive form of finance for a company as the shareholders are the highest risk taker at the time of liquidation of the company.

DTE ratio is used to measure total debt in each year for ${ }^{3}$ each listed company. The DTE of a company increases if the debt proportion in its financial mix increases compared to equity portion. If the ratio is $1: 1$, this means that 50 percent of the assets are financed by equity. But if it increases to $2: 1$ then it means that 67 percent of the assets are financed by the equity; that shows the poor position of the company at the time of liquidity. The acceptable range of DTE in each industry varies. Lately, the State Bank of Pakistan issued a used. This is defined as total liabilities divided by total equity of the firm. The mechanism followed for ratio comparison is the general accounting principle that if the ROA of the company increases and the ROE also show a higher increase, this indicates that the figures obtained are authentic and are justifying each other. One other check applied for its authenticity is the value of DTE. If an increase in ROE is about two-fold to the increase in ROA and the DTE also shows a ratio of $2: 1$, then the values are aligned. The study checked all these ratios of each year for all 69 listed companies of seven business groups and in the years where the debt value was far above the ROA and ROE values. These years are considered as periods when access to debt of these firms was beyond their financial performance. This indicates that some special privileges were given to the companies in that particular year or that some other special thing had occurred in the company that year. This then is backed with the investigation of the major corporate decisions taken by the business in that year and this is explained in detail in a case study of Nishat Group.

\section{Empirical Analysis of Nishat Group}

The Nishat Group is currently Pakistan's largest business group with fixed/ current assets of over Rs.300 billion (US $\$ 5$ billion) and the CEO of this group Mian Mansha is considered the country's richest man. In 1970, the Mansha family business was the fifteenth largest ${ }^{4}$; in 1990 it jumped to sixth and just three years later it became the largest enterprise in corporate Pakistan. What happened during those three years is mostly credited to Mansha's close acquaintance with the then Prime Minister, Nawaz Sharif. However, Mansha's business intellect and ability to make the right decisions at the right time also helped.

In 1948, Mansha's father, Mian Mohammad Yahya, and his three brothers incorporated a partnership called the Nishat Corporation. The

statement that the DTE cannot be more than 4:1 for any company. See Table $1^{4}$ 1815 
company was named after Nishat Haroon, the three year old grandson of Mian Mohammad Yaqub, the eldest of the four brothers. Later, the child who gave his name to the group was not the one who took charge of the company. Rather, Mian Mohammad Mansha, the second son of Mohammad Yahya took charge of the Nishat Group.

Nishat Haroon was born to Mian Farooq, who was married to the daughter of Mian Fazal Rehman of United Textile Mills. In 1970, Nishat comprised six firms in West Pakistan, namely Nishat Corporation, Nishat Sarhad Textile, Nishat Textile Mills (Faisalabad), Nishat Chemical Industries, Nishat Agencies (Kotri) and Karimi Industries (Nowshera). The companies in East Pakistan included Nishat Jute Mills, Qadaria Textile Mills, Tangail Cotton Mills and Chemical Industries of Pakistan. The business in East Pakistan was headed by Aftab Iqbal, one of several cousins of Mian Mansha, whose whereabouts is not known today. Mian Muhammad Mansha was born in Lahore and belongs to a wealthy Chiniot family. His privileged upbringing allowed him to enjoy an early business education at a top university in London. When the division of Nishat Group assets took place in 1969 after the death of his father, Mansha bargained for Nishat Mills, based in
Faisalabad, for which he had to pay an additional amount to his uncles. This act saved him from losses in East Pakistan that became the lot of his uncles. Nishat currently comprises 21 enterprises including 13 listed companies with manufacturing assets of nearly Rs. 27 billion. Three of Mansha's close relatives, Saigols, Jehangir Elahi and S.M. Saleem of United Bank, are among the top 45 industrial families in Pakistan. Nishat is Pakistan's largest industrial and financial conglomerate, controlling assets worth Rs.192 billion. The group company structure is indicated in Figure 1.

The ownership structure of the Nishat Group in Figure 1 indicates that its control of the publiclisted companies of the group is through two holding companies, Nishat Chunnian and Nishat Pak. The Group's assets were parcelled out to these two subgroups, or holding companies, in the 1990s. The Nishat Pak group was led by Mian Mansha and the Nishat Chunnian group was led by a nephew of Mian Mansha. Nishat Pak is considered one of the best managed business groups in Pakistan's corporate sector. Through these two holding companies, the Group control companies involved in a range of sectors, including in textiles, power generation, insurance, banking and cement production. 


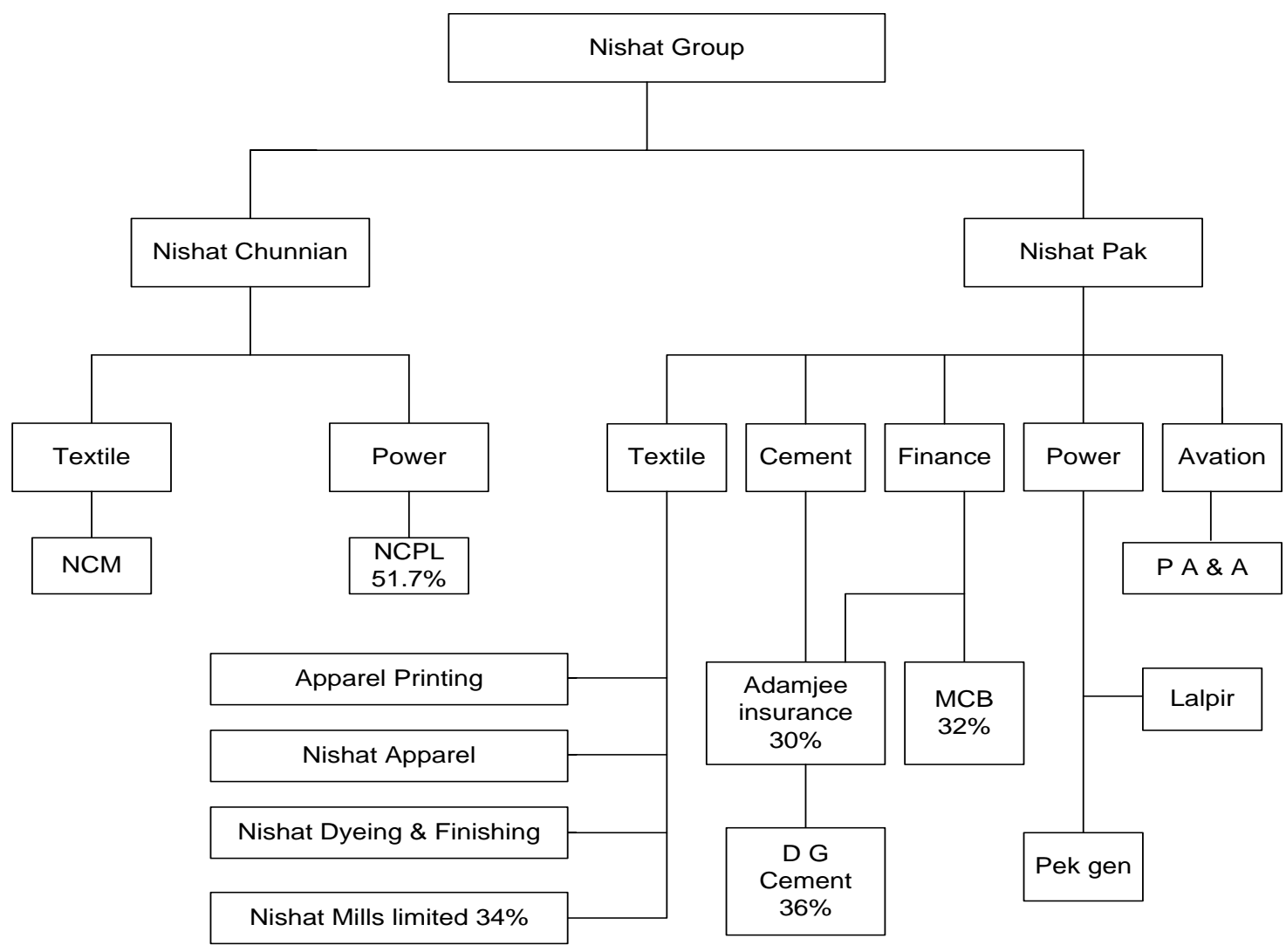

Figure 1: Company structure \& shareholding Pattern of Nishat Group.

\section{Source: Author}

The Group has majority share ownership of these firms, providing the family the ability to control decision-making in all companies, as per Porta's theory. The company structure also indicates that the group which started out in the textile industry had expanded into the cement production, finance and power sectors, emerging as a highly diversified conglomerate. These have been fastest growing industries over the last twenty years in Pakistan.

A detailed analysis of the shareholding pattern of the companies of the Nishat Group indicated the presence of a large number of associated firms or institutional investors. For example, in D.G. Khan Cement, institutional investors holds the dominant position with 48 percent of total shares, while in Sanofi Aventis, a foreign holding company M/s. SECIPE, France holds a 81 percent stake. In
MCB, the largest shareholders are associated companies, collectively controlling more than 50 percent of total shares; foreign investors have a 16 percent stake. In Adamjee Insurance, the ownership structure is one where equity is quite evenly spread between associated companies (36 percent), institutional investors (31 percent) and general public (30 percent). But out of institutional investors, again MCB holds 82 percent of shares.

This study analysed the companies listed on the Karachi stock exchange on August 2013. It examined eight public listed companies of the Nishat Group representing its participation in the textile, financial, power, and cement sectors. The name of the companies and information about them are listed in Table 2. 
Table 2:Public listed companies \& year of association with Nishat Group.

\begin{tabular}{|l|l|l|l|}
\hline No & Company Name & Industry & Group ownership \\
\hline 1$)$ & Nishat Mills Limited & Textile & 1956 \\
\hline 2$)$ & Nishat Chunnian Limited & Textile & 1991 \\
\hline 3$)$ & DG Cement & Cement & 1992 \\
\hline 4$)$ & Adamjee Insurance & Insurance & 1992 \\
\hline 5$)$ & Muslim Commercial Bank (MCB) & Financial & 1991 \\
\hline 6$)$ & Nishat Chunnian Power & Power & 2010 \\
\hline 7$)$ & Nishat Power & Power & 2010 \\
\hline 8$)$ & PakGen & Power & 2010 \\
\hline
\end{tabular}

\section{Source: Author}

To grade the performance of the business groups, based on three major ratios, i.e. their return-onassets (ROA), return-on-equity (ROE) and debtto-equity (DTE), under different regimes, a statistical analysis was conducted. In this study, the ROA, ROE and DTE of each group for each year were classified as per regime, from regimes 1 to 8 . This was done to determine if there were any significant differences in the performance of business group under different regimes. Based on the performance indicators, ROA, ROE and DTE, the change in the performance of all groups during their date of incorporation until 2012 was studied. The significance of the analysis of these three ratios was checked by applying one-way ANOVA $^{5}$. The ANOVA test was applied using all the three ratios, representing also their ability to access loans, represented in their DTE ratio. The ANOVA test shows that the values of all three measured variables are significant.

The ANOVA analysis proves that the performance of the group varied under different regimes; all three measured variables, ROA, ROE and DTE indicated much variation. This proves that the $\mathrm{H} 1$ proposition is true, allowing for the application of the Duncan test $^{6}$ to grade the

See page 106 for the hypotheses of this study. ${ }^{5}$ Duncan's multiple range test, or Duncan's test, provides 6 significance levels for the difference between any pair of means, regardless whether a significant $F$ resulted from an initial analysis of variance. group's performance, from best to worst, as per regimes.

To verify the argument that Nishat Group benefited by networking with political elites, a financial analysis of the group was also conducted. The DTE test was applied to determine under which regime this variable was the highest. The results show that DTE was the highest during the mixed democracy (MD). When comparing all three variables, they should support each other, but Nishat Group's ratio analyses offer a different picture. When the average of all ratios for each regime was taken, the average DTE for the Nishat Group was highest in the MD regime.

According to the rules of finance, the Group's ROA should also be highest compared to other regimes during the MD period; however, the results do not support this rule. The average ROA of the Nishat Group was only 1.024 percent during the MD, but its DTE was 10.27 times higher. This means that the group had been able to increase its debt ratio, as compared to its equity, much more during the MD period; this contention is supported by its other performance indicator, i.e. ROA. The easiest and least expensive source of debt for any firm is bank loans. Nishat Group was able to obtain huge loans which were not backed by its ability to repay them as its ROA figures did not show any positive or encouraging results. This suggests that during the MD period, when Nawaz Sharif was in power, Mian Mansha's close ties with him allowed his group to be favoured when seeking loans. 
The group expanded on the basis of loans from banks, which normally becomes accessible on the basis of political contacts and rent seeking activities. The Group's slow but continuous expansion and entry into different industries indicates the trust of shareholders in this group. The Mansha family was also able to win the trust of shareholders, through continuous dividend disbursement and investment decisions in emerging industries that generated much returns.

This study further observed the financial performance of the Nishat Group under different regimes. As debt is the cheapest source of finance, though it helped increase profitability, the company's DTE soared to 10.27 times during the MD regime. Meanwhile, the ROA was only 1.02 percent, which was not that strong to support such DTE figures. There is one major reasons for this increased DTE. During the MD regime, Nishat obtained control of the bank, MCB, after its privatization. Normally the DTEs of banks are higher as their major form of growth is the disbursement of loans, which increases their debt ratio. To check this, when the DTEs of individual companies were measured, MCB plays a major role in the increase of the average DTE ratio of this regime see Table 3 .

Table 3: Comparative analysis of Ratios of listed companies of Nishat Group of listed companies of Nishat Group

\begin{tabular}{|c|c|c|c|}
\hline $\begin{array}{c}\text { Items/ } \\
\text { Years }\end{array}$ & Nishat & & \\
\hline & ROA & ROE & DTE \\
\hline $1 \mathrm{MR}$ & 7.864 & 12.15 & 0.982 \\
\hline $2 \mathrm{MR}$ & 3.815 & 7.383 & 0.881 \\
\hline 1DR & -1.699 & -7.972 & 1.901 \\
\hline $3 \mathrm{MR}$ & 2.232 & 11.61 & 1.145 \\
\hline MD & 1.024 & 11.1 & 10.27 \\
\hline 4MR & 1.852 & 15.44 & 10.08 \\
\hline 1DT & 3.191 & 16.64 & 3.937 \\
\hline
\end{tabular}

\section{Analysis of Results:}

\section{Financial:}

When all the results discussed above are combined then Table 5 shows a rapid increase in DTE during the MD regime was due to the inclusion of Muslim Commercial Bank (MCB) in Nishat Group. Since it is a bank and financial institutions' DTEs are always high, this suddenly increased the Group's DTE. Apart from MCB, the DTEs of other companies during the MD regime increased, compared to previous regimes.

\section{Interpretation:}

MCB is a bank and its major performance is measured on the basis of their loan disbursing ability and this increased the Group's debt ratio. Another channel used by business groups to network is by creating personal friendships with political leaders (Ali and Malik 2009, Rehman 1998) noted that special favors were granted to the Nishat Group during the first tenure of Nawaz Sharif, from 1991 to 1993 . The privatization of the Muslim Commercial Bank (MCB) to Mian Mansha and his associates was seen as an act of favoritism by Nawaz Sharif when he was Prime Minister. When the government decided to privatize MCB, Mansha's bid was the third highest of the five that had been tendered. Even so, Nawaz Sharif's government chose Mansha. 
This was then considered, in the history of Pakistan, the biggest benefit a business group had obtained because of its political connections. Nishat Group's estimated assets in 1990 were about Rs4 billion, but according to the group's profile in 1993 the value of its assets was approximately Rs10 billion, a phenomenal 250 percentage point increase in just three years.

MCB was sold for Rs. 2,420 million against a down-payment of Rs. 804 million. Within a year of the privatization of MCB, the Privatization Commission sold some of the most profitable cement plants to Mian Mansha, his relatives and business associates. D G Khan Cement was sold to Tariq Saeed Saigol for Rs. 1,799 million, Maple Leaf Cement to Nishat Mills for Rs. 291 million, and Pak Cement and White Cement for Rs. 137 million and Rs. 188 million respectively to Mian Jehangir Elahi and Associates. Dandot Cement was sold to the Chakwal Group for Rs. 254 million. D G Cement was acquired by Kohinoor Textile Mills (KTM), owned by Tariq Saeed Saigol, by borrowing heavily from the bank. This is evident from the annual reports of KTM for 1992 which show no debt, while the 1993 accounts reveal heavy indebtedness.

Nishat Mills had assumed the management of Maple Leaf Cement on January 8, 1992. However, within a few months of the sale of D G Khan Cement by KTM to Mian Mansha, Maple Leaf Cement was sold by Mian Mansha to Tariq Saeed Saigol. KTM had also invested in the privatization of White Cement and Pak Cement but its investment was also divested in March 1992, in favor of Mian Mansha. Dandot Cement was officially privatized to employees group, but somehow it has become a part of Chakwal Group, also closely related in business to Mian Mansha.

It was through complex intercorporate financing that Mian Mansha, his relatives and business associates ended up with five of eight privatized cement units which accounted for 45 percent of total industrial assets privatized by Sharif. Within months of their privatization, cement prices catapulted in the domestic market, forcing the government to order the dormant Monopoly
Control Authority (MCA) to hold an inquiry into the possibility of the cartelization of cement. As expected, the inquiry absolved the privatized units of any wrongdoing.

It was because of the assets acquired through privatization that the Nishat Group, which was at the $15^{\text {th }}$ position among the list of 43 top industrial families in Pakistan in 1972 and sixth in the ranking of the Monthly Herald in 1990, had risen to the top of the corporate world in 1993, when Sharif was dismissed on charges of corruption and other irregularities. Nearly half of the assets privatized by Sharif ended up with Mansha, his relatives or business associates. However, bringing together the National Group to bid for Muslim Commercial Bank (MCB) was the biggest business coup that the Chiniotis could have staged against their main business rivals. Before nationalisation, the MCB was a Memon bank owned by Adamjee, and its purchase by Chiniotis demonstrated their rising power and the decline of the Memons. The National Group which bought MCB was a consortium of 12 leading industrial families, of whom all but two, Chakwal and Bashir Jan Mohammad, were not Chinioti. While MCB was the flagship of the Chiniotis, now a rising power, they called upon a Memon banker, Hussain Lawai, to head it.

It is on record that when Benazir Bhutto came to power in 1993, she developed amnesia about her pledge to investigate the privatization of the MCB to Nishat Group during Sharif's regime. Apparently, after a meeting between MCB's President, Hussain Lawai, and Prime

Minister Bhutto's spouse Asif Zardari, a deal was struck. It is not known what transpired during this meeting but within a week of it Mian Mansha went into forced exile, to return to

Pakistan only after the ouster of Bhutto in November 1996. It was only after the dismissal of her government that the collusion between Lawai and Zardari was exposed involving several deals such as the award of a gold monopoly to ARY 
Traders ${ }^{7}$, a loan to Sadaruddin Hashwani (CEO of Hashoo Group) to facilitate the purchase of Occidental Petroleum ${ }^{8}$ and the dubious UBL privatization to Basharahill ${ }^{9}$ (Rehman 1998).

\section{Conclusion}

Pakistan's corporate sector is still controlled by local business groups which are primarily familyowned, and apart from the strong involvement of MNCs, the economy is deeply influenced by the local power elites, particularly the agricultural and industrial resource owners. However, Pakistan has also been deeply affected by the strategic decisions of the superpowers, especially those taken at the time of the Cold War and in the postSeptember 11 period; their impact on the country's economy is evident. The presence of international actors in the Pakistani economy has contributed to its development and growth.

When Nawaz Sharif, with a business background, joined politics and became Finance Minister in 1980 to 1985 in Zia's regime and later Chief Minister of Punjab, he changed the previous track of business activities. The political attention and decisions related to the corporate sector took a

Chief of Dubai-based ARY Gold, Haji Abdul Razzaq, ${ }^{7}$ denied giving any kickbacks to former Pakistani Premier Bhutto. http://m.gulfnews.com/news/uae/general/ary-chiefdenies-kickbacks-to-get-licence-1.393380 Occidental said it had sold a portion of its operations in ${ }^{8}$ Pakistan to Zaver Petroleum Corp., an affiliate of the Hashoo Group, a leading Asian conglomerate. The price was not disclosed. Zaver acquired Occidental's subsidiary that owned properties in northern Pakistan's Potwar Basin, which include interests in the Dhurnal and Bhangali oil and gas fields and the Ratana gas field. Those fields currently produce 4,200 barrels of oil and liquid petroleum gas and 25.2 million cubic feet of natural gas per day. Occidental retains a significant interest in the Badin Block in southern Pakistan and seven recently acquired exploration blocks totaling 8.7 million acres in northern and central Pakistan. http://www.upi.com/Archives/1995/04/17/Occidental-sellsthree-assets/9802798091200/ The US\$17 million deal (for a 26 percent stake) was 9 reportedly pushed through by the legal advisor to the Basharahill group for UBL to the State Bank of Pakistan. Concerns over the financial stability of Basharahill, a company incorporated in Gibraltar with a paid-up capital of some 2000 pounds appeared to be alleviated as the company was entirely taken over by Prince Nawaf Bin Abdul-Aziz Al Saud, for US\$400 million. http://www.Pakistaneconomist.com/database2/cover/c9635.asp major shift from Karachi (Sindh) to Faisalabad (Punjab). Pakistan found a new Chinioti corporate elite competing with the well-established old corporate elite of Karachi. This new elite created new strategy to secure state patronage in the shape of personal links and networking. This situation gave a new dimension to the corporate sector, in the shape of the individual business groups rising under different regimes based on their own personal contacts with the ruling elite of a particular regime.

After Zia's long military regime of eleven years, over the next decade Pakistan faced eight (four elected and four caretaker) governments. During the era of these eight governments, a new mode of doing business was adopted by big business groups. It was about developing close acquaintances with the ruling elite to secure access to state rents as there existed an uncertainty about the sustainability of the policies with governments constantly changing. The corporate sector which appeared to be flourishing was a boon for both big and small businesses. After the reversal of the nationalization policy, business groups focused on securing individual benefits by developing political connections rather than working in a collective manner to promote overall corporate sector development. This philosophy is still being followed as the country's economic conditions have worsened after energy crises and continuous incidents of terrorism.

Corporate elites had acquired companies at firesale prices through privatization. The purpose of privatizing public sector companies was to transfer their liabilities to the new owners. But, in practice, these new owners failed to repay these liabilities and had to be cleared by the government. In the words of Rehman (2006): "the unkindest cut inflicted by the privatization of Benazir and Nawaz Sharif on the people of Pakistan related to the liabilities of the privatized units". The Benazir and Nawaz governments had privatized 88 industrial units by October 15, 1996, for a consideration of Rs. 15,409 million, out of which Rs. 4 billion was in default, involving the owners of 30 privatized units. Of these 30 owners, 
13 have not paid a single penny after assuming control of privatized units.

On Dec 1, 1995, the top 43 groups owned 212 of the 522 non-financial companies listed on the Karachi Stock Exchange (KSE) accounting for 43 percent of the total manufacturing assets; this figure excludes those owned by multinationals and public sector enterprises. Out of the 175 listed, 76 belonged to these categories: banking companies, modarabas ${ }^{10}$, leasing and financial companies. Their power was clustered in textile, sugar, cement, insurance, banks and modarabas while almost all the newly-listed captive power plants belonged to these groups. Together they owned at least 122 textile mills, 19 sugar mills, eight cement plants, 12 insurance companies, 11 banks, 16 modorabas, eight leasing companies and seven power plants. This indicates the concentration of wealth in these few business families, a factor that strengthened them financially. However, the continuous drop in GDP rates along with other poor development indicators suggested that this expansion of corporate sector did not trickle down to the masses. This suggests a link with the increasing foreign assets of these business groups to evaluate the corporate value of political connections of business firms in Pakistan, this study followed (Faccio. 2007) theory of political-business connections. Faccio did an analysis of multiple countries to find out the common characteristics of countries with widespread political connections. Some of the variables analyzed in this study to evaluate political connections are derived from Faccio, Masulis, and McConnell (2006) such as large shareholders and officers of firm's entering politics and corruption. For measuring the effect on financial performance, the variables were derived from Boubakri, Cosset, and Saffar (2008) such as return-on-assets (ROA)

An agreement between two or more persons whereby one ${ }^{10}$ or more of them provide finance, while the other(s) provide entrepreneurship and management to carry out a business venture, whether trade, industry or service, with the objective of earning profits. The profit is shared in an agreed proportion. The loss is borne by the financiers only in proportion to their share in the total capital. and return-on-equity (ROE). But added to this was the figurative ratio of debt to equity (DTE), applied as an indicator for political connection, in line with Dinc's (2005) argument about the political influence of government-owned banks in emerging markets. The firm was seen as politically connected if its DTE provided higher rates, which were not supported by the returns on assets and equity of the firm.

The results of business groups' financial and ownership structure in this study are consistent with the arguments made by Faccio (2006) and Shleifer and Vishny (1994) i.e. that politicians extract rents from companies which they help by providing them access to bank loans. These firms are also favored during privatization and the issuance of licenses for new industrial projects, for example in tax-free zones. Nevertheless, Faccio concluded that firm value increases more if the businessperson is elected prime minister of the country. Although, in case of Pakistan, the firm value increases if the elected prime minister is a close acquaintance of the businessmen as the politicians do not remain the CEO of any big organizations.

\section{References}

[1] Ahlstrom, David, Michael N Young, Eunice S Chan, and Garry D Bruton. 2004. "Facing constraints to growth? Overseas Chinese entrepreneurs and traditional business practices in East Asia." Asia Pacific Journal of Management no. 21 (3):263-285.

[2] Ali, Imran, and Adeel Malik. 2009. The political economy of industrial development in Pakistan: A long-term perspective. Lahore Journal of Economics no. 14 (Special Edition):29-50. doi: https://doi.org/10.35536/lje.2009.v14.isp.a 3.

[3] Amjad, Rashid. 1976. Industrial concentration and economic power in Pakistan. Pakistan Economic and Social Review no. 14 (1/4):211-261. 
[4] Anderson, Ronald C, and David M Reeb. 2003. "Founding-family ownership, corporate diversification, and firm leverage." The Journal of Law and Economics no. 46 (2):653-684. doi: https://doi.org/10.1086/377115.

[5] Asquer, R., and F. Calderoni. 2011. Family matters: Testing the effect of political connections in Italy. Center for the Study of Democracy.

[6] Baron, David P. 1995. "Integrated strategy: Market and nonmarket components." California Management $\begin{array}{llll}\text { Review no. } 37 \text { (2):47-65. doi: } & \end{array}$ https://doi.org/10.2307/41165788.

[7] Bertrand, Marianne, Simon Johnson, Krislert Samphantharak, and Antoinette Schoar. 2008. Mixing family with business: A study of Thai business groups and the families behind them. Journal of Financial Economics no. 88 (3):466-498. doi:

https://doi.org/10.1016/j.jfineco.2008.04.0 02.

[8] Boddewyn, Jean J, and Thomas L Brewer. 1994. "International-business political behavior: New theoretical directions." Academy of Management Review no. 19 (1):119-143. doi: https://doi.org/10.5465/amr.1994.9410122 010.

[9] Boubakri, Narjess, Jean-Claude Cosset, and Walid Saffar. 2008. "Political connections of newly privatized firms." Journal of Corporate Finance no. 14 (5):654-673.

[10] Bunkanwanicha, Pramuan, and Yupana Wiwattanakantang. 2009. "Big business owners in politics." The Review of Financial Studies no. 22 (6):2133-2168. doi: https://doi.org/10.1093/rfs/hhn083.

[11] Bunkanwanicha., P., J. P. Fan, and Y. Wiwattanakantang. 2008. "Why do shareholders value marriage?" Unpublished Manuscript, Chinese University Hong Kong.
[12] Carney, Michael, and Eric Gedajlovic. 2002. The co-evolution of institutional environments and organizational strategies: The rise of family business groups in the ASEAN region. Organization Studies no. 23 (1):1-29. doi: https://doi.org/10.1177/017084060223100 1.

[13] Claessens, Stijn, Erik Feijen, and Luc Laeven. 2008. "Political connections and preferential access to finance: The role of campaign contributions." Journal of Financial Economics no. 88 (3):554-580. doi:

https://doi.org/10.1016/j.jfineco.2006.11.0 03.

[14] Cook, Ronald G, and Dale R Fox. 2000. "Resources, frequency, and methods: An analysis of small and medium-sized firms' public policy activities." Business \& Society no. 39 (1):94-113. doi: https://doi.org/10.1177/000765030003900 107.

[15] Cuervo-Cazurra, Alvaro. 2006. "Business groups and their types." Asia Pacific Journal of Management no. 23 (4):419437. doi: https://doi.org/10.1007/s10490006-9012-5.

[16] Desai, Raj M, and Anders Olofsgård. 2011. "The costs of political influence: Firm-level evidence from developing countries." Quarterly Journal of Political Science no. 6 (2):137-178. doi: https://doi.org/10.1561/100.00010094.

[17] Faccio, Mara, Ronald W Masulis, and John J McConnell. 2006. "Political connections and corporate bailouts." The Journal of Finance no. 61 (6):2597-2635. doi: $\quad$ https://doi.org/10.1111/j.15406261.2006.01000.x.

[18] Faccio., M. 2007. "The characteristics of politically connected firms."

[19] Fan, J. P., T. J. Wong, and T. Zhang. 2007. Politically connected CEOs, corporate governance, and post-IPO performance of China's newly partially privatized firms. 
Journal of Financial Economics no. 84 (2):330-357. doi: https://doi.org/10.1016/j.jfineco.2006.03.0 08 .

[20] Ferguson, Thomas, and Hans-Joachim Voth. 2008. "Betting on Hitler - the value of political connections in Nazi Germany." The Quarterly Journal of Economics no. $123 \quad$ (1):101-137. doi: https://doi.org/10.1162/qjec.2008.123.1.10 1.

[21] Filatotchev, Igor, Yung-Chih Lien, and Jenifer Piesse. 2005. "Corporate governance and performance in publicly listed, family-controlled firms: Evidence from Taiwan." Asia Pacific Journal of Management no. 22 (3):257-283. doi: https://doi.org/10.1007/s10490-005-35692.

[22] Fisman, Raymond. 2001. "Estimating the value of political connections." American Economic Review no. 91 (4):1095-1102. doi: https://doi.org/10.1257/aer.91.4.1095.

[23] Getz, K. 1996. Politically active foreignowned firms in the US: Elephants or chickens. Beyond Us and Them: Foreign Ownership and US Competitiveness.

[24] Ghani, WaQar, Omair Haroon, and Muhammad Junaid Ashraf. 2010. "Business groups' financial performance: Evidence from Pakistan." Global Journal of Business Research no. 5 (2):27-39.

[25] Gomez, Edmund Terence. 2009. "The rise and fall of capital: Corporate Malaysia in historical perspective." Journal of Contemporary Asia no. 39 (3):345-381. doi:

https://doi.org/10.1080/004723309029444 04.

[26] Hansen, Wendy L, and Neil J Mitchell. 2000. "Disaggregating and explaining corporate political activity: Domestic and foreign corporations in national politics." American Political Science Review no. 94 (4):891-903. doi: https://doi.org/10.2307/2586214.
[27] Haq, M. U. 1976. The poverty curtain: Choices for the third world. New York: Columbia University Press.

[28] Hillman, Amy J, and Michael A Hitt. 1999. "Corporate political strategy formulation: A model of approach, participation, and strategy decisions." Academy of Management Review no. 24 (4):825-842.

doi: https://doi.org/10.2307/259357.

[29] Hillman, Amy J, Gerald D Keim, and Douglas Schuler. 2004. "Corporate political activity: A review and research agenda." Journal of Management no. 30 (6):837-857.

[30] Hussain, Akmal. 1985. "Pakistan: The crisis of the state."

[31] Javid, A. Y., and R. Iqbal. 2008. "Ownership concentration, corporate governance and firm performance: Evidence from Pakistan." The Pakistan Development Review no. 47 (4 Part II):643-659. doi: https://doi.org/10.30541/v47i4iipp.643659.

[32] Keim, Gerald, and Barry Baysinger. 1988. "The efficacy of business political activity: Competitive considerations in a principalagent context." Journal of Management no. 14 (2):163-180. doi: https://doi.org/10.1177/014920638801400 203.

[33] Khanna, Tarun, and Jan W Rivkin. 2001. "Estimating the performance effects of business groups in emerging markets." Strategic Management Journal no. 22 (1):45-74. doi: https://doi.org/10.1002/10970266(200101)22:1<45::aidsmj147>3.0.co;2-f.

[34] Khanna., T., and K. Palepu. 2000b. "Is group affiliation profitable in emerging markets? An analysis of diversified Indian business groups." The Journal of Finance no. 55 (2):867-891. 
[35] Khanna., T., and Y. Yafeh. 2005. "Business groups in emerging markets: Paragons or parasites?" ECGI-Finance Working Paper No. (92).

[36] Khawaja, A., and A. Mian. 2009. "Do lenders favor politically connected firms." Rent Provision.

[37] Khwaja, A. I., A. Mian, and A. Qamar. 2008. "The value of business networks." Unpublished Manuscript.

[38] Kim, Jeong-Bon, and Cheong H Yi. 2006. "Ownership structure, business group affiliation, listing status, and earnings management: Evidence from Korea." Contemporary Accounting Research no. 23 (2):427-464. doi: https://doi.org/10.1506/7t5b-72fv-mhjve697.

[39] Kosacoff, Bernardo. 2000. "Corporate strategies under structural adjustment in Argentina: Responses by industrial firms to a new set of uncertainties."

[40] Lee, Keonbeom, Mike W Peng, and Keun Lee. 2008. "From diversification premium to diversification discount during institutional transitions." Journal of World Business no. 43 (1):47-65. doi: https://doi.org/10.1016/j.jwb.2007.10.010.

[41] Leff, Nathaniel. 1976. "Capital markets in the less developed countries: The group principle." Money and Finance in Economic Growth and Development no. 3 (1):97-126.

[42] Li, Hongbin, Lingsheng Meng, Qian Wang, and Li-An Zhou. 2008. Political connections, financing and firm performance: Evidence from Chinese private firms. Journal of Development Economics no. 87 (2):283-299. doi: https://doi.org/10.1016/j.jdeveco.2007.03. 001.

[43] Luo, Xiaowei, and Chi-Nien Chung. 2005. "Keeping it all in the family: The role of particularistic relationships in business group performance during institutional transition." Administrative Science Quarterly no. 50 (3):404-439.

[44] Maniruzzaman, Talukder. 1966. "Group interests in Pakistan politics, 1947-1958." Pacific Affairs no. 39 (1/2):83-98. doi: https://doi.org/10.2307/2755183.

[45] Maury, Benjamin. 2006. "Family ownership and firm performance: Empirical evidence from Western European corporations." Journal of Corporate Finance no. 12 (2):321-341. doi: https://doi.org/10.1016/j.jcorpfin.2005.02. 002.

[46] Papanek, Hanna. 1972. "Pakistan's big businessmen: Muslim separatism, entrepreneurship, and partial modernization." Economic Development and Cultural Change no. 21 (1):1-32. doi: https://doi.org/10.1086/450605.

[47] Raman, K Ravi. 2014. "Business, Ethnicity, Politics, and Imperial Interests: The United Planters' Association of Southern India, 1893-1950." Business History Review no. 88 (01):73-95.

[48] Rashid, S. H. 1980. Industrial development in Pakistan from 1947 to 1970: An overview: Kansas State University.

[49] Rehman, S. U. 1998. Who owns Pakistan? Fluctuating fortunes of business mughals: S. Rehman.

[50] Saeed, M. A. 2013. Do political connections matter? Empirical evidence from listed firms in Pakistan: Middlesex University.

[51] Saeed., A., Y. Belghitar, and E. Clark. 2014. "Political connections and leverage: Firm-level evidence from Pakistan." Managerial and Decision Economics.

[52] Schuler, Douglas A, and Kathleen Rehbein. 1997. "The filtering role of the firm in corporate political involvement." Business \& Society no. 36 (2):116-139. doi: https://doi.org/10.1177/000765039703600 202. 
[53] Shleifer, Andrei, and Robert W Vishny. 1994. "Politicians and firms." The Quarterly Journal of Economics no. 109 (4):995-1025. doi: https://doi.org/10.2307/2118354.

[54] Steven, White. 2004. "Stakeholders, structure and the failure of corporate governance reform initiatives in post-crisis Thailand." Asia Pacific Journal of Management no. 21 (1-2):103-122. doi: https://doi.org/10.1023/b:apjm.000002407 9.34567.5c.

[55] Tsui, Anne S. 2004. "Contributing to global management knowledge: A case for high quality indigenous research." Asia Pacific Journal of Management no. 21 (4):491-513.

[56] Villalonga, Belen, and Raphael Amit. 2006. "How do family ownership, control and management affect firm value?" Journal of Financial Economics no. 80 (2):385-417. doi: https://doi.org/10.1016/j.jfineco.2004.12.0 05 .

[57] Wang, Hui-mei, Hengchiang Huang, and Pratima Bansal. 2005. "What determined success during the Asian Economic Crisis?-The importance of experiential knowledge and group affiliation." Asia Pacific Journal of Management no. 22 (1):89-106.

[58] White, L. J. 1974. Industrial concentration and economic power in Pakistan. Princeton: Princeton University Press.

[59] Whitley, Richard. 1994. "Dominant forms of economic organization in market economies." Organization Studies no. 15 (2):153-182. 